\title{
"THE GREAT AMERICAN COMPETITIVE DISADVANTAGE: FACT OR FICTION?”: A REPLY
}

\author{
DONALD L. STERNITZKE* \\ Bowling Green State University
}

In their comment on "The Great American Competitive Disadvantage: Fact or Fiction?", D. Ricks, M. Czinkota, and G. DeJesus point out several criticisms of share analysis, especially those made by Houston [2] and Richardson [3, 4], and suggest that perhaps share analysis may be too suspect to be of much use. Because these issues-together with several other caveats on the use of share analysis - may have an influence on the results obtained, they are discussed in my article for the benefit of readers who are not familiar with the share-analysis technique. However, in their note, Ricks, Czinkota, and DeJesus fail to consider the reply made by Ashby [1] to the issues raised by Houston nor do they recognize that Richardson concludes his article by suggesting several ways to improve the results of share analysis rather than advocating that the method should not be used at all [3].

The use of share analysis in the study of trends in American exports is justified on several points. First, the results of the analysis are offered as one more piece of evidence on the nature of the American export problem and are consistent with some other studies on the problem. Second, two of the problems associated with share analysis (as suggested by Ricks, Czinkota, and DeJesus) are attributable to the need to aggregate data and the lack of quantity shares at the level of aggregation actually used; however, when applied to particular industry groups, the chances are that these problems may be less important, thereby improving the usefulness of the results to firms in these industries. Third, and perhaps most importantly, the proper use of share analysis is to classify what has happened in the recent past so that other, more dynamic tools of analysis can be used more effectively to find the exact causes of the vexing problems faced by American exporters.

1. Ashby, Lowell D. "The Shift and Share Analysis: A Reply." Southern Economic Journal, January 1968, pp. 423-425.

2. Houston, David. "The Shift and Share Analysis of Regional Growth: A Critique." Southern Economic Journal, April 1967, pp. 577-581.

3. Richardson, J. David. "Constant-Market-Share Analysis of Export Growth." Journal of International Economics, May 1971, pp. 227-239.

4. "Some Sensitivity Tests for a 'Constant-Market-Shares' Analysis of Export Growth." The Review of Economics and Statistics, August 1971, pp. 300-304.

\footnotetext{
${ }^{\star}$ Dr. Donald L. Sternitzke is Professor of Economics, College of Business Administration, Bowling Green State University. His research interests include the problems encountered by businesses in international trade and the impact of international monetary events on

world trade flows.
}

\section{REFERENCES \\ REFERENCES}

